\title{
EXCHANGE RATE DETERMINATION BY ARTIFICIAL NEURAL NETWORKS: THE TURKISH CASE
}

\section{YAPAY SİNIR AĞLARI ARACILIĞIYLA DÖVIZ KURUNU BELİRLEME: TÜRKIYYE ÖRNEĞİ}

\author{
Ayça SARIALİĞLU HAYALİ ${ }^{1}$, Hasan Törehan BABACAN ${ }^{2}$
}

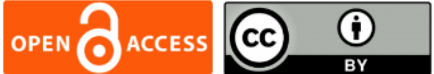

1. Assoc. Prof. Dr., Karadeniz Technical University, Department of Economics,

aycasarialiogluhayali@ktu.edu.tr, https://orcid.org/0000-0002-6613-7531

2. Lecturer, Doctoral Candidate, Amasya University, Department of Transportation Services, Karadeniz Technical University, Department of Civil Engineering, hasan.babacan@amasya.edu.tr, https://orcid.org/0000-0001-9570-1966

Makale Türü

Araştırma Makalesi

Basvuru Tarihi

26.09.2020

Yayına Kabul Tarihi

21.07.2021
Admission Date

07.21 .2021

Article Type

Research Article

Application Date

09.26 .2020

DOI

\section{Abstract}

Artificial Neural Networks as one of the Artificial Intelligence applications, which is the leading candidate for the greatest innovation of the century, has been started to be used in solving the complex problems of the economy for a while. Among them, predicting the exchange rate is one of the utmost important complex issues to be determined especially for the small open economies, such as Turkey, where the changes in exchange rate influence all the other variables in the economy, from macro variables to microones. This paper aims to analyze the exchange rate determination between Turkish Lira and American Dollar by using Artificial Neural Networks through the Monetarist Model. As a result, very close results to the real values were obtained. It can be said that although in exchange rate estimation both Artificial Neural Networks -Levenberg Marquardt and Artificial Neural Networks-Quasi-Newton models give good results, the Artificial Neural Networks -Levenberg Marquardt model is more successful in general terms.

Keywords: Artificial Neural Networks, Exchange Rate Determination, the Turkish Case.

Öz

Yüzyılın en büyük inovasyonu için öncü aday olan Yapay Zeka uygulamalarından biri olarak Yapay Sinir Ağları, bir süredir ekonominin karmaşık problemlerini çözmekte kullanılmaya başlanmıştır. Onların arasında, döviz kurunu tahmin etme, döviz kurundaki değișikliğin makro değişkenlerden mikro değişkenlere kadar ekonomideki diğer tüm değişkenleri etkilediği Türkiye gibi özellikle küçük açık ülkeler için belirlenmesi gereken en önemli karmaşık konulardan biridir. Bu makale, Türk Lirası ve Amerikan Doları arasındaki Döviz Kurunu belirmeyi parasalcı modeller kapsamında Yapay Sinir Ağlarını kullanarak analiz etmeyi amaçlamaktadır. Sonuç olarak, gerçek değerlere çok yakın sonuçlar elde edilmiştir. Söylenebilir ki döviz kuru tahmininde hem Yapay Sinir Ağlar1- Levenberg Marquardt hem de Yapay Sinir Ağlar1- Quasi-Newton modelleri iyi sonuç verse de Yapay Sinir Ağları- Levenberg Marquardt modeli genel anlamda daha başarılıdır.

Anahtar Kelimeler: Yapay Sinir Ağları, Döviz, Kuru Belirleme, Türkiye Örneği. 


\section{Çalışmanın Amacı}

\section{GENIŞLETILMIŞ ÖZET}

$\mathrm{Bu}$ makale, Türk Lirası (TL) ile Amerikan Doları (\$) arasındaki döviz kuru belirlemesini Parasalcı Model aracılığıyla Yapay Sinir Ağları (YSA) kullanarak analiz etmeyi amaçlamaktadır.

\section{Araştırma Soruları}

YSA döviz kuru belirlemesinde iyi bir tahmin edici olabilir mi? Parasalcı Model aracılığıyla YSA, Türk Lirası (TL) ile Amerikan Doları (\$) arasındaki döviz kurunun belirlenmesinde iyi sonuçlar verir mi?

\section{Literatür Araştırması}

Literatürde, farklı konuları ele alan sosyal bilimlerde YSA kullanan birçok çalışma bulunmaktadır. Onlar arasında, Karaatlı vd. (2012) karar vericilere otomotiv endüstrisi hakkındaki politikaları konusunda yardımcı olmak amacıyla gelecekteki otomotiv satışlarının miktarını tahmin etmektedir; Altunöz (2013) bir erken uyarı sistemi olarak Türk bankalarının finansal başarısızlığını tahmin etmeye çalışmaktadır; Kocatepe ve Yıldız (2016), araştırmacılara ve yatırımcılar gibi karar vericilere katkı sağlamak amacıyla altın fiyatlarındaki değişimi tahmin etmeye çalışmaktadır; Yüksel ve Akkoç (2016) altın fiyatlarını tahmin etmeye çalışmaktadır; Çuhadar ve Kayacan (2005), konaklama işletmelerinde doluluk oranlarını tahmin etmede yeni bir yöntem tanıtarak, Türk turizm literatürüne katkı sağlamak amacıyla dış turizm talebi tarafından oluşturulan otel mülkü doluluk oranlarını tahmin etmeye çalışmaktadır ve Erilli vd. (2010), politika yapıcılarına fiyat istikrarını sağlamada katkıda bulunmak amacıyla enflasyon oranlarını tahmin etmeye çalışmaktadır. Diğer tarafta, YSA kullanarak TL ve \$ arasındaki döviz kuru tahminiyle uğraşan az sayıda çalışma bulunmaktadır. Onlar arasında, Altan (2008) sonuçların performanslarını karşılaştırmak amacıyla hem YSA hem de Vektör Otoregresif (VAR) Modelini kullanarak döviz kuru tahmini yapmaya çalışmaktadır. Özkan (2011) ise gecikmeli kur değerlerine sahip zaman serisi modeli, Parasal Model ve Satın Alma Gücü Paritesi Modeli olmak üzere üç farklı model üzerinden YSA kullanarak TL/ABD Doları ve TL/Euro döviz kurlarını tahmin etmeye çalışmaktadır.

\section{Yöntem}

İnsandaki biyolojik nöron sistemine benzer şekilde çalışabilen ve makine öğrenmesi yapabilen YSA, katman ve düğümlerden oluşan ve çok sayıda fonksiyonu paralel olarak çalıştırabilen sayısal yöntemdir. Yöntem, doğrusal veya doğrusal olmayan fonksiyonların paralel biçimde çalışarak elde ettiği ağırlık değerleri ile oluşturulmuş denklemler aracılığıyla, ilişkileri ve bu ilişkilerin dereceleri çok boyutlu uzay içinde bilinmeyen veri setlerinin çözümlerini araştırır. Bu sayede, önceki çalışmalar bu yöntemin regresyon modellerine göre daha başarılı olduğunu göstermektedir (Mansouri vd., 2016). Genel olarak YSA yapısında Girdi, Gizli ve Çıktı Katmanları olmak üzere üç farklı katman bulunmaktadır. Girdi Katmanı, bilgiyi dışarıdan ağa alan kısımdır. Bu bilgiler Girdi Katmanında nöron olarak bilinen dügümlere aktarılır ve daha sonra sırasıyla Gizli Katmana ve Çıktı Katmanına aktarılır 
(Yüksek vd., 2018). Bu çalışmada, 2001 yılının 12'sinden başlayarak 2017'nin 3'üne kadar IMF Uluslararası Finansal İstatistiklerinden elde edilen aylık veri seti kullanılmıştır. Bu bağlamda, para arzı (m), reel çıktı (y), faiz oranı (i), enflasyon oranı (П) ve net yabancı varlıklar (r)'ın yerli (Türkiye) ve yabancı (ABD, * ile sembolize edilen) değişkenleri Parasal Modeller aracılı̆̆ıyla kullanılmıştır. Veri setinin yüzde 70'i $(\approx 129$ birim) ağın eğitimi için, veri setinin yüzde 30'u ( $\approx 55$ birim) ise eğitilen ağın test aşaması için kullanılmıştır.

\section{Sonuç ve Değerlendirme}

YSA yapılarının ekonomik veya finansal tahminler ve modellemelerde, özellikle küçük açık ekonomiler için belirlenmesi gereken en önemli karmașık konulardan biri olan döviz kurlarının tahmininde başarıyla kullanılabileceği tespit edilmiştir. Bunun nedeni döviz kurlarının tahmin edilmesinin birçok faktörü bir arada değerlendirmeyi gerektirmesidir ve YSA, yapısında böyle bir kapasiteye sahip görünmektedir. Bu çalışmada, döviz kuru tahmini için yapılan analizlerde gerçek değerlere çok yakın sonuçlar elde edilmiştir. Döviz kuru tahmininde hem ANN-LM hem de ANN-QN modelleri iyi sonuçlar vermesine rağmen genel anlamda ANN-LM modelinin daha başarılı olduğu söylenebilir. 


\section{INTRODUCTION}

Today Artificial Intelligence (AI) applications, which are generally based on the simulation of the human brain by the machines, are used in every field by having successful outcomes. In this regard, Artificial Neural Networks (ANN) as one of the AI applications is used in solving the complex problems of the economy, engineering and social sciences issues as follows: The prediction of the amount of commercial product sales; the determination of the economic success of the foundations and the estimation of the gold prices, inflation rates etc. Among them, prediction of the exchange rates is one of the utmost important complex issues to be determined especially for the small open economies, such as Turkey, where the changes in exchange rate influence all other variables in the economy, from macro variables such as inflation, to micro variables such as balance sheets of the companies. Prediction of the exchange rates through ANN is a relatively new but promising method since the topic itself requires considering several factors together and ANN seems to have such capacity in its structure.

This paper aims to analyse the exchange rate determination between Turkish Lira (TL) and American Dollar (\$) by using ANN through the Monetarist Model. As a different method from the existing literature using ANN, in this paper ANN-Levenberg Marquardt (LM) and ANN-Quasi-Newton (QN) methods, which were formulated by the LM and QN learning algorithms, have been used. Different from the methods used in the existing literature in this paper, among the methods that have been used, Hyperbolic Tangent Sigmoid (HTS) and Logarithmic Sigmoid (LS) transfer functions and the success of 2, 5, 10 neuron numbers in the hidden layer have been investigated for the 5 different input combinations that were formulated.

In the paper, after the introduction part the topic is tacked in two parts before the conclusion. In the first part, a brief literature review dealing with the works using ANN in social sciences especially, the ones determining the exchange rates, and in the second part, the Methodology of the paper take place. As sub-groups of the Methodology part, ANN is introduced first and then the data set and application of ANN and the findings and interpreting the findings are tacked, respectively.

\section{LITERATURE REVIEW}

In literature, there are several works using ANN in social sciences dealing with the different issues. Among them, Karaatl et al. (2012) predict the amount of future automotive sales in order to help decision-makers on their policies about the automotive industry; Altunöz (2013) tries to predict the financial failure of the Turkish banks as an early warning system; Kocatepe and Yildiz (2016) try to forecast the change in gold prices in order to contribute to researchers and decision-makers such as investors; Yüksel and Akkoç (2016) try to predict the gold prices; Çuhadar and Kayacan (2005) try to predict the hotel property occupancy rates that are generated by the foreign tourism demand in order to contribute to the Turkish tourism literature through introducing a new method in forecasting occupancy 
rates in accommodation establishments and Erilli et al. (2010) try to estimate the inflation rates in order to contribute to policymakers in maintaining price stability. On the other hand, there are few works dealing with the exchange rate prediction between TL and \$ by using ANN. Among them, Altan (2008) tries to do exchange rate estimation by using both ANN and vector autoregressive (VAR) model in order to compare the performances of the results. Ozkan (2011) tries to predict the TL/US Dollar and TL/Euro exchange rates by using ANN through three different models including time-series model with lagged exchange rate values, Monetary Model and Purchasing Power Parity (PPP) model.

In this regard, Karaatli et al. (2012), which use the monthly data between January-2007 and June-2011, find out that the predictions for the amount of future automotive sales and the real values are close to each other except for the two months, October and November, which are regarded as they influenced mostly the end year discounts in December. Altunöz (2013), which uses the annual data for the era of 1997-2002, finds out that ANN performs well in predicting the financial failure for both 1 and 2 years before the financial failure, with the $88 \%$ success and $77 \%$ success, respectively. Kocatepe and Yildiz (2016), which use the monthly data between 2007 and 2015 and one month lagged values of the independent variables, find out that the success rate of forecasting changes in price direction of gold (Increase/Decrease), which is proxied by the monthly price change per gram of gold in Turkey, is $75.24 \%$ of which performance is accepted as successful. Yüksel and Akkoç (2016), which use the daily data between $03.01 .2002-31.10 .2013$, find out that ANN can be successfully used to estimate the gold prices, which are proxied by the prices of per ons of gold in their study and the major factors that affect the gold prices are silver and oil prices according to the results of the sensitivity analysis that they conducted. Çuhadar and Kayacan (2005), which use the annual data between 1990 and 2002, find out that the values forecasted are very close to the real values and these forecasts are accompanied by very low error rates. Erilli et al. (2010), which use the monthly data for the period of February 2003-June 2008, maintain that ANN can have advantages over any time-series analysis. This is due to the prior conditions for time-series analysis, such as a linear or nonlinear specific model pattern, stationary and normal distribution are not required by ANN. They find out that the predictions, which are obtained by using a new combined forecast based on ANN in which the ANN model predictions employed in analysis were used as data, perform generally well in predicting the inflation rates in Turkey except for the three months, such as July 2007, January 2008 and June 2008.

Altan (2008), which uses the monthly data between January 1987 - September 2007 for TL/US Dollar, finds out that the success of the projections for exchange rate has increased through ANN, in which multilayered feed forward artificial neural network architecture and back propagation learning method are conducted. Moreover, Altan (2008) maintains that ANN performs better than VAR especially in predicting the 1994 and 2001 crises of Turkey, which place within the sample period. Ozkan (2011), which uses the monthly data between 1986-2010 for the American Dollar and 1999-2010 for Euro, finds out that ANN gave the best results for the time-series model of the lagged values of the 
exchange rates when compared with the models constructed by using the variables of PPP and Monetary Model, which was ranked second for the performance of the ANN.

\section{METHODOLOGY}

\subsection{Artificial Neural Networks}

ANN, which can work similar to the biological neuron system in human and make machine learning, is the numerical method consisting of layer and nodes that can make functions in parallel way. The method investigates the solutions of the data sets of which relationships and the degrees of such relationships are not known within the multidimensional space by the equations working in parallel that are not obligated to the linear or nonlinear functions. Thanks to this, the previous works show that such method is more successful compared to regression models (Mansouri et al., 2016). In general, there are three different layers as input, hidden and output layers in ANN structure. Input layer is the part that gets the information from outside to the network. Such information is transferred to the nodes, known as neuron, in input layer and then transferred to hidden layer and output layer, respectively (Yüksek $e t$ al., 2018). The structure of ANN is shown in Figure 1.

The structure of ANN is spread into two in literature as Feed Forward and Feed Forward Back Propagation in terms of the evaluation of the error rate of the data and making the influence of the error rate into next application. In the Feed Forward ANN structure, the weights (w) and bias $(\mathcal{E})$ which were initially selected randomly are appointed to the connections of the nodes in the layers and used in the transfer function. The data that is entered into the network from the input layer after going to the hidden layer and output layer, respectively, are compared with the target data in terms of the goal error. If the error term is high, then the network does this transaction again till the error terms decrease. At last, w and $\mathcal{E}$ results that gave the best results are fixed to connections. Within the framework of the Feed Forward Back Propagation ANN structure, in the Back Propagation ANN architecture the high error terms are used in reappointing the coefficients in the connections via learning function and the new coefficients and network work in opposite directions. In the Feed Forward Back Propagation ANN structure, the two transactions work parallel (Öztemel, 2003). It is maintained that Feed Forward Back Propagation ANN structure has higher performance values than the Feed Forward ANN structure (Schalkoff, 1997; Babacan, 2015). 
Figure 1. The General Structure of ANN

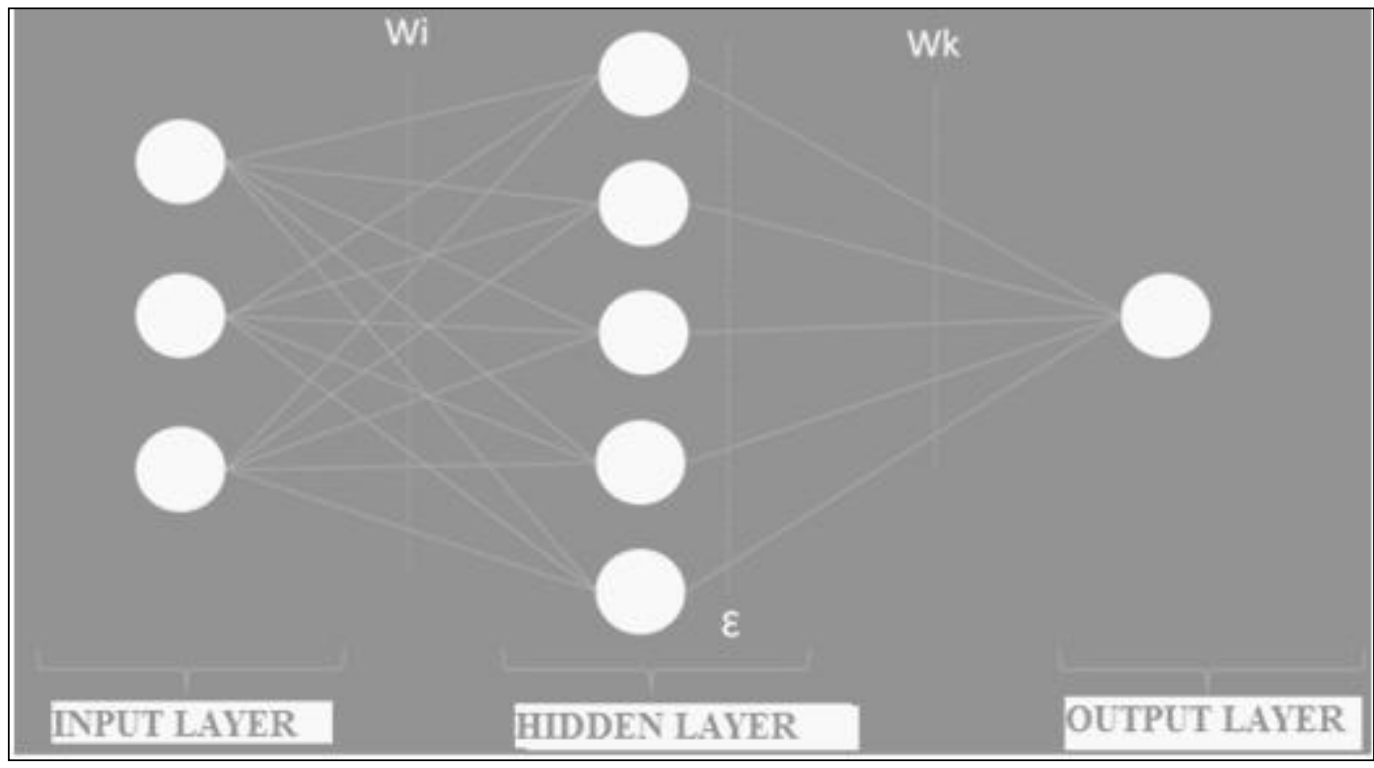

\subsection{Data Set and Conducting the ANN}

In this study, monthly data set, which were all obtained from the International Monetary Fund (IMF) International Financial Statistics, starting from the 12th of the 2001 to the 3rd of the 2017 were used. In this regard, domestic (Turkey) and foreign (USA, symbolized by *) variables of money supply $(\mathrm{m})$, real output (y), interest rate (i), inflation rate (П) and net foreign assets (r) were used through monetary models (Frankel, 1984). The 70 percent of the data set ( $\approx 129$ units) is used for the training of the network and the 30 percent of the data set ( $\approx 55$ units) is used for the test stage of the trained network. The data used were normalized within the interval of $[0,1]$ by the following Formula of Equation 1 in order to increase the performance of the network (Kalender and Hamzaçebi, 2014).

$$
\mathrm{X}_{\mathrm{n}}=\mathrm{X}-\mathrm{X}_{\min } / \mathrm{X}_{\max }-\mathrm{X}_{\min }
$$

In the Equation $1, X_{n}$ symbolizes the normalized data, $X$ symbolizes the raw data, $X_{\min }$ symbolizes the minimum value of the data set and $X_{\max }$ symbolizes the maximum value of the data set.

By using the values obtained 5 different input parameters and by these parameters, 5 different input combinations were conducted, which are indicated in Table 1. Since the relationship and the degree of the relationship of the data set of the input combinations are not known, main input parameter is designed according to P1 for the most available relationship levels. The other parameters are tried gradually with the P1 of which relation with the predicting data set is thought to be strong. 
Table 1. The ANN Input Combinations

\begin{tabular}{|c|c|c|c|c|}
\hline COMBINATION & \multicolumn{4}{|c|}{ INPUT } \\
\hline M1 & P1 & & & \\
\hline M2 & P1 & P2 & & \\
\hline M3 & P1 & P2 & P3 & P4 \\
\hline M4 & P1 & P2 & P3 & P4 \\
\hline M5 & P1 & P2 & P3 & \\
\hline
\end{tabular}

\section{Notes:}

P1: $\left(\mathrm{m}_{\mathrm{t}}-\mathrm{m}_{\mathrm{t}}{ }^{*}\right)$ where $\mathrm{m}_{\mathrm{t}}$ corresponds to the $\log$ of the domestic nominal money supply and $\mathrm{m}_{\mathrm{t}}$ * corresponds to the log of the foreign nominal money supply.

P2: $\left(\mathrm{y}_{\mathrm{t}}-\mathrm{y}_{\mathrm{t}} *\right)$ where $\mathrm{y}_{\mathrm{t}}$ corresponds to $\log$ of the domestic real output and $\mathrm{y}_{\mathrm{t}} *$ corresponds to $\log$ of the foreign real output.

P3: $\left(i_{t}-i_{t}{ }^{*}\right)$ where $i_{t}$ corresponds to the domestic interest rate and $i_{t} *$ corresponds to the foreign interest rate.

P4: $\left(\Pi_{\mathrm{t}}-\Pi_{\mathrm{t}}{ }^{*}\right)$ where $\Pi_{\mathrm{t}}$ corresponds to the domestic inflation rate and $\Pi_{\mathrm{t}} *$ corresponds to the foreign inflation rate.

P5: $\left(r_{t}-r_{t}{ }^{*}\right)$ where $r_{t}$ corresponds to the domestic net foreign assets and $r_{t}^{*}$ corresponds to the foreign net foreign assets.

Determining the optimum model of ANN structure in this study is important for the further studies. So, for the ANN structure two different structures were formed by the LM and QN learning algorithms (Moré, 1978; Gill et al., 1981). In order to determine the optimum selection of the transfer function, which is a significant parameter for the ANN structures, the HTS and LS sigmoid type functions, which were positively resulted most in the literature, were tried for the ANN-LM and ANNQN. For the number of agents in the hidden layer, which is another factor that influence the performance of the network, in each analysis the optimum numbers of 2, 5 and 10 neurons, which were determined by the trial-error-method, were conducted. The different network architectures that were conducted and the Analysis Flow Chart are shown in the following Figure 2. 
Figure 2. The Analysis Flow Chart

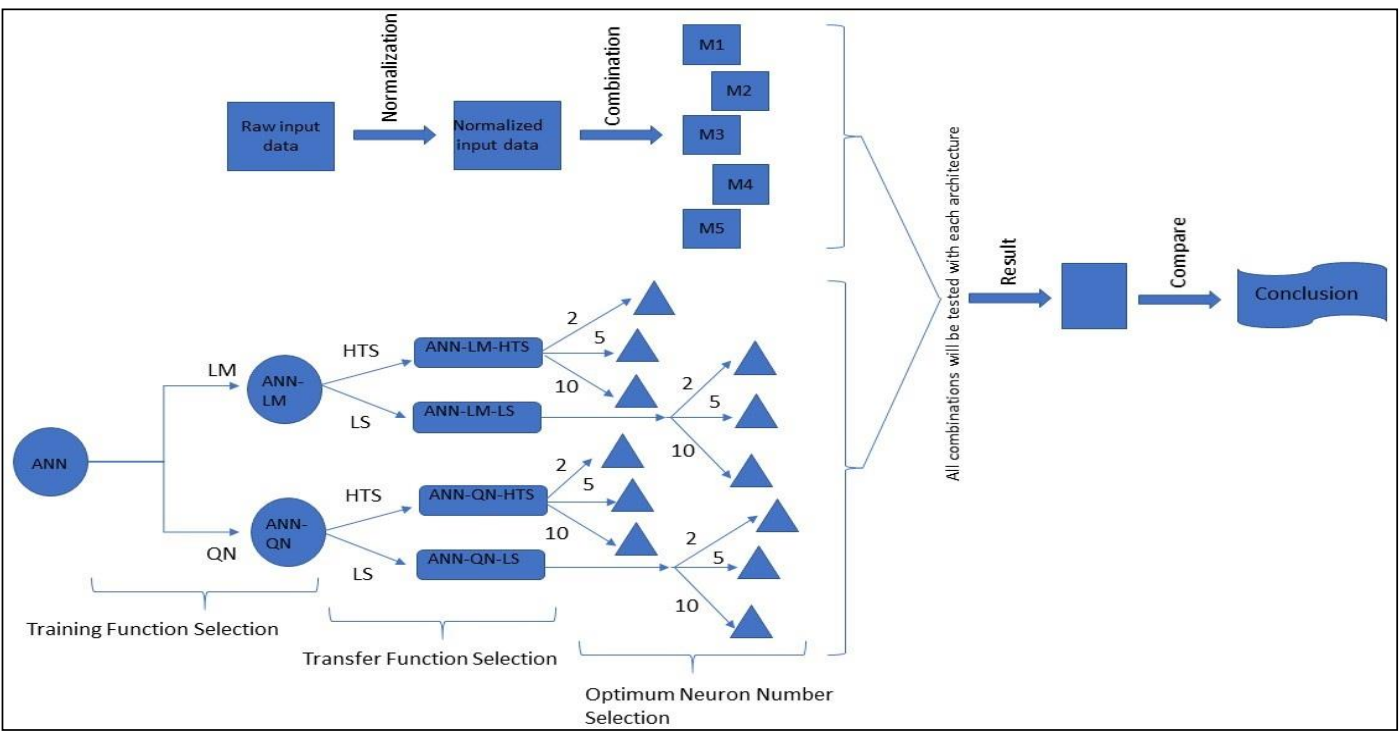

\subsection{Findings and Interpretation}

In order to determine the Exchange Rate (TL/\$) by the ANN method in this study, the optimum structure of ANN was investigated. The results of the different structures, which were formed for ANNQN structure that were tried by the input models in Table 1, are seen in Table 2. When it is looked at Table 2, the input combination which has the highest performance for the ANN-QN structure is M4. If M4 is compared with M5 in Exchange Rate (TL/\$) estimation, it is seen that there is no positive effect

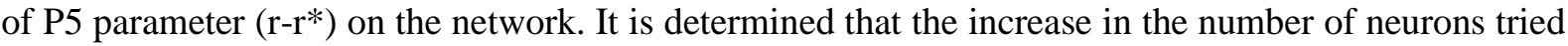
in the hidden layer affected the stability level of the network and decreased its performance and moreover the highest performance was sustained with 2 neurons.

It is seen that the success rate of the LS transfer function is less than the HTS transfer function and the network makes value memorization. In sum, it is found out that, in the ANN-QN method, the most successful structure was determined by the M4 input combination, 2 neurons in hidden layer HTS transfer function.

Table 2. ANN-QN Performance Data

\begin{tabular}{|c|c|c|c|}
\hline \multicolumn{2}{|c|}{$\begin{array}{c}\text { Transfer } \\
\text { Function }\end{array}$} & Logarithmic Sigmoid & Hyperbolic Tangent Sigmoid \\
\hline HLNN & IC & R & R \\
\hline \multirow{4}{*}{2} & M1 & 0.939 & 0.557 \\
\cline { 2 - 4 } & M2 & 0.526 & 0.909 \\
\cline { 2 - 4 } & M3 & 0.826 & 0.683 \\
\cline { 2 - 4 } & M4 & 0.512 & 0.997 \\
\hline \multirow{4}{*}{5} & M5 & 0.888 & -0.385 \\
\cline { 2 - 4 } & M1 & -0.576 & 0.949 \\
\cline { 2 - 4 } & M3 & -0.688 & 0.869 \\
\cline { 2 - 4 } & M4 & 0.948 & -0.834 \\
\hline \multirow{nyyy}{*}{10} & M5 & 0.750 & 0.506 \\
\hline
\end{tabular}




\begin{tabular}{|c|c|c|c|}
\hline \multirow{4}{*}{} & M2 & 0.657 & -0.720 \\
\cline { 2 - 4 } & M3 & -0.736 & 0.944 \\
\cline { 2 - 4 } & M4 & -0.495 & -0.673 \\
\cline { 2 - 4 } & M5 & -0.496 & 0.852 \\
\hline
\end{tabular}

Notes: The Model that has the highest performance is indicated in bold font.

HLNN: Hidden Layer Neuron Number; IC: Input Combination

It is seen that in the analyses that were done by ANN-LM in estimating the output, the inputs are more successful and the network do not make any value memorization. When it is looked at Table 3 , it is seen that the performance of the networks are negatively affected by the increase in the number of neurons tried in the hidden layer. As seen in ANN-QN structure, the HTS transfer function produces more successful results than LS transfer function. In sum, it is found out that, in the ANN-LM method, the most successful structure was determined by the M5 input combination, 2 neurons in hidden layer HTS transfer function. When Table 2 and table 3 are examined, it is determined that LM Algorithm work in higher performance than $\mathrm{QN}$ algorithm in estimating exchange rate.

Table 3. ANN-LM Performance Data

\begin{tabular}{|c|c|c|c|}
\hline \multicolumn{2}{|c|}{$\begin{array}{c}\text { Transfer } \\
\text { Function }\end{array}$} & Logarithmic Sigmoid & Hyperbolic Tangent Sigmoid \\
\hline HLNN & IC & R & 0.939 \\
\hline \multirow{4}{*}{2} & M1 & 0.557 & 0.909 \\
\cline { 2 - 4 } & M2 & 0.909 & 0.826 \\
\cline { 2 - 4 } & M3 & 0.683 & 0.540 \\
\cline { 2 - 4 } & M4 & 0.997 & 0.998 \\
\hline \multirow{4}{*}{5} & M5 & 0.888 & 0.780 \\
\cline { 2 - 4 } & M1 & 0.751 & 0.832 \\
\cline { 2 - 4 } & M2 & -0.017 & 0.956 \\
\cline { 2 - 4 } & M4 & -0.981 & 0.552 \\
\hline \multirow{4}{*}{10} & M5 & -0.976 & 0.092 \\
\cline { 2 - 4 } & M1 & 0.848 & 0.579 \\
\cline { 2 - 4 } & M2 & -0.896 & 0.492 \\
\cline { 2 - 4 } & M3 & 0.665 & 0.974 \\
\cline { 2 - 4 } & M4 & 0.034 & -0.308 \\
\hline
\end{tabular}

Notes: The Model that has the highest performance is indicated in bold font.

HLNN: Hidden Layer Neuron Number; IC: Input Combination

The scatter and time-series diagrams for the ANN-LM (2-HTS-M5) network structure are shown in the following Figure 3. It is determined that the negative values seen in Figure 2 are the ones that were produced by the network as the correspondences of the values close to zero and the success of the network was not affected from this. It is observed that the estimations done by the ANN-LM (2HTS-M5) network structure are in line with the observed values and the network produce estimations that are very close to the real values. 
Figure 3. The ANN-LM (2-HTS-M5) Scatter and Time-Series Diagrams

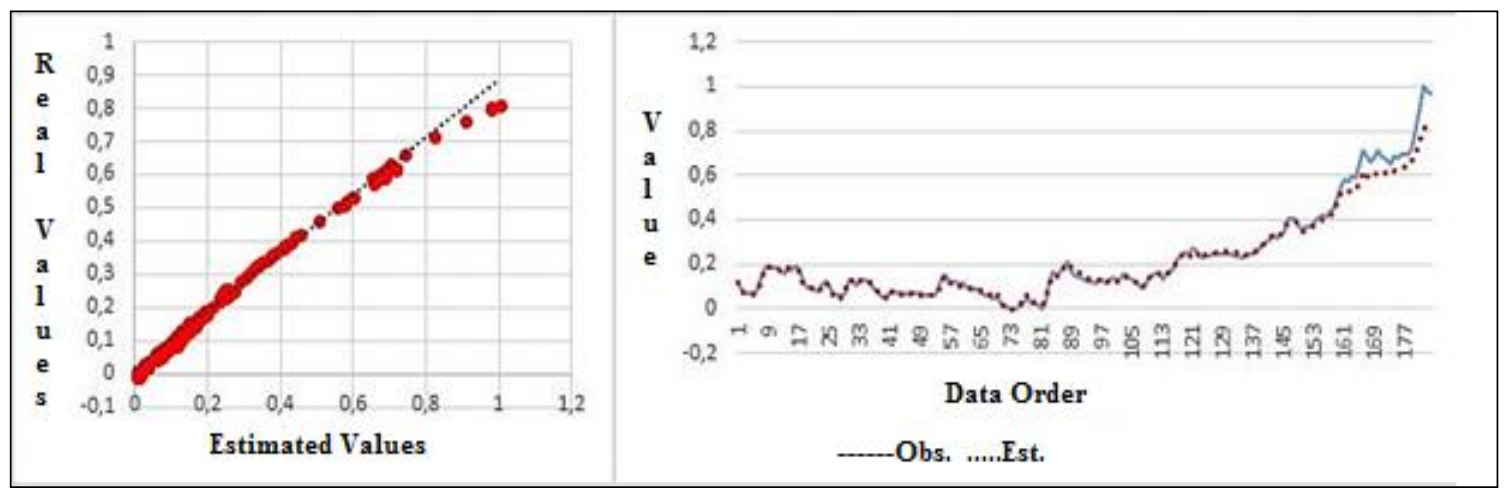

\section{CONCLUSION}

It is found out that ANN structures can be used successfully for the economic or financial estimations and modelling especially for predicting the exchange rates, which is one of the utmost important complex issues to be determined especially for the small open economies, since predicting the exchange rates requires considering several factors together and ANN seems to have such capacity in its structure.

In this study, in the analyses for the exchange rate estimation very close results to the real values were obtained. It can be said that although in exchange rate estimation both ANN-LM and ANN-QN models have given good results, the ANN-LM model is more successful in general terms. In this regard, the paper tries to fill the gap in the existing literature using ANN by conducting a different method from the existing literature such as using ANN-LM and ANN-QN methods and among the methods that were used, HTS and LS transfer functions and the success of 2,5,10 neuron numbers in the hidden layer were investigated for the 5 different input combinations that were formulated. The further studies in the future for exchange rate estimation by trying different learning algorithms and different transfer functions beside the ANN-LM and ANN-QN structures would gain a new perspective to the existing literature.

\section{REFERENCES}

Altan, Ş. (2008). Döviz kuru öngörü performansı için alternatif bir yaklaşım: Yapay sinir ağı. Gazi Üniversitesi İktisadi ve İdari Bilimler Fakültesi Dergisi, 10(2), 1-20.

Altunöz, U. (2013). Bankaların finansal başarısızlıklarının yapay sinir ağları modeli çerçevesinde tahmin edilebilirliği. Dokuz Eylül Üniversitesi İktisadi ve İdari Bilimler Fakültesi Dergisi, 28(2), 189-217.

Babacan, H.T. (2015). Giresun İli Aksu Deresi için farklı parametreler kullanılarak yapay sinir ağları ile aklş modellemesi ve ileriye dönük akım tahminleri yapılması. (Yayımlanmamıș Yüksek Lisans Tezi- Unpublished Master's Thesis). Gümüşhane Üniversitesi Fen Bilimleri Enstitüsü, Gümüşhane.

Çuhadar, M. and Kayacan, C. (2005). Yapay sinir ağları kullanılarak konaklama işletmelerinde doluluk oranı tahmini: Türkiye'deki konaklama işletmeleri üzerine bir deneme. Anatolia: Turizm Arastirmalari Dergisi, 16(1), 24-30. 
Erilli, N.A., Eğrioğlu, E., Yolcu, U., Aladağ, Ç.H. and Uslu, V.R. (2010). Türkiye'de enflasyonun ileri ve geri beslemeli yapay sinir ağlarının melez yaklaşımı ile öngörüsü. Doğuş Üniversitesi Dergisi, 11(1) 2010, 42-55.

Frankel, J.A. (1984). Tests of Monetary and Portfolio Balance Models of Exchange

Rate Determination (Eds), John F. O. Bilson and Richard C. Marston, In Exchange Rate Theory and Practice (239- 260). USA: University of Chicago Press.

Gill, P.E., Murray, W., and Wright, M.H. (1981). Practical Optimization. California, USA: Elsevier Academic Press.

International Monetary Fund, International Financial Statistics, https://data.imf.org/.

Kalender, F.Y., and Hamzaçebi, C. (2014). Yapay sinir ağlari ile Türkiye'de net enerji talep tahmini. Gazi Üniversitesi Mühendislik-Mimarlık Fakültesi Dergisi, 29(3).

Karaatlı, M., Helvacığlu, Ö.C., Ömürbek, N., and Tokgöz, G. (2012). Yapay sinir ağları yöntemi ile otomobil satış tahmini. Uluslararası Yönetim, İktisat ve İşletme Dergisi, 8(17), 87-100.

Kocatepe, C.İ., and Yıldız, O. (2016). Ekonomik endeksler kullanılarak Türkiye'deki altın fiyatındaki değişim yönünün yapay sinir ağları ile tahmini. Düzce Üniversitesi Bilim ve Teknoloji Dergisi, 4(3), 926-934.

Mansouri, A., Nazari, A., and Ramazani, M. (2016). A comparison of artificial neural network model and logistics regression in prediction of companies' bankruptcy (A case study of Tehran Stock Exchange). International Journal of Advanced Computer Research, 6(24), 81-92.

Moré, J.J. (1978). The Levenberg-Marquardt Algorithm: Implementation And Theory. In Numerical Analysis (105-116). Berlin, Heidelberg: Springer.

Öztemel, E. (2003). Yapay Sinir A ğları. Istanbul: PapatyaYayıncılık.

Schalkoff, R.J. (1997). Artificial Neural Networks (Vol. 1). New York: McGraw-Hill.

Yüksek, Ö., Babacan, H.T., and Saka, F. (2018). Yağış-Akış Modellemesinde Optimum Yapay Sinir Ağı Yapısının Araştırılması. Türk Hidrolik Dergisi, 2(1), 31-37.

Yüksel, R., and Akkoç, S. (2016). Altın fiyatlarının yapay sinir ağları ile tahmini ve bir uygulama. Doğuş Üniversitesi Dergisi, 17(1), 39-50. 